\title{
O subsolo da Crítica - Uma conferência inédita de Lebrun sobre Kant
}

A conferência aqui transcrita foi proferida por Gérard Lebrun em São Paulo na noite de 7 de novembro de 1995, uma terçafeira, no salão nobre do antigo prédio da Faculdade de Filosofia, situado na Rua Maria Antonia, e é uma das duas que Lebrun apresentou no âmbito do ciclo $A$ crise da razão, organizado por Adauto Novaes e promovido pela Funarte. A outra, intitulada "Sobre a tecnofobia", foi publicada no volume A crise da razão (Organização Adauto Novaes. São Paulo: Companhia das Letras, 1995). O jornal Folha de São Paulo deu notícia da palestra de Lebrun sobre Kant em matéria assinada por Marcelo Rezende e publicada no caderno ilustrada em 9/11/1995. (ver apêndice; a matéria foi recuperada para a Discurso por Dario Galvão). O texto da fala de Lebrun permaneceu inédito, e pôde ser reconstituído, em toda a sua exuberante coloquialidade franco-brasileira, graças a um registro em vídeo. A presente transcrição, realizada por Maria Lúcia Cacciola e Maurício Keinert, e editada por Pedro Paulo Pimenta, mantém-se fiel às palavras de Lebrun na ocasião, alterando-as tão somente quando as regras do portu- 
guês assim o exigem de maneira imprescindível ou em caso da ocorrência de falsos cognatos ou de termos com sentido próximo nas duas línguas, porém inexato. Como se trata de uma conferência, não de um artigo, e como todas as referências textuais feitas por Lebrun são alusivas, e remetem a capítulos e seções de Kant, não a textos precisos, a transcrição não tem notas nem bibliografia.

Lebrun escolhe um tema que não poderia ser mais coerente com sua trajetória intelectual. Trata-se de examinar na obra de Kant o tema das diferentes legislações da sensibilidade e da razão, resumido por Lebrun com este adágio, "nunca macular os inteligíveis". A fascinante exposição leva Lebrun a comentar as origens em Kant da noção nietzscheana de "interpretação", Deutung, numa investigação que prolonga reflexões que vinham sendo desenvolvidas desde Kant e o fim da metafísica (1970) e, ao longo da década de 70, em textos depois reunidos em Sobre Kant (1992) e Kant sans kantisme (2009). Como de costume, a história da filosofia, manejada com maestria inigualável, e a filologia, utilizada com precisão, servem a Lebrun como pretexto para alçar voo numa especulação própria, fincada no tempo presente.

Os mais de vinte anos que nos separam desta exposição não foram suficientes para obliterar o fato de que esse tempo continua a ser o nosso. Esse mesmo período testemunhou um fenômeno interessante. A obra de Lebrun foi reeditada na França, alguns de seus escritos brasileiros (mas não todos) foram publicados pela primeira vez no país de origem do filósofo, e seu pensamento começou a ser valorizado enquanto tal. No Brasil o surgimento de A filosofia e sua história (2006) veio confirmar a riqueza de um corpus teórico que ainda não foi inteiramente 
explorado. Que a publicação desta conferência possa contribuir para a permanência de Lebrun no horizonte filosófico brasileiro, do qual, desde a sua inserção na década de 1960, ele nunca esteve ausente.

Os Editores

$* * *$

A Crítica da razão pura, que Kant, com 57 anos, publicou em 1781, não era destinada de forma alguma a refutar a metafísica, mas, ao contrário, a tornar enfim possível a existência de uma metafísica que fosse ciência, visto que a metafísica como ciência nunca existiu. Kant não foi o único a pensar isso na Alemanha da Aufklãrung, era um tema comum na época comparar o estado humilhante da metafísica com o majestoso edifício da matemática, constituída entre os gregos, e com o edifício mais recente, a física-matemática de Newton. Por certo a metafísica é uma ciência, e se se chamam ciências as disciplinas lecionadas nas universidades, os estudos universitários ainda conservavam a sombra dela. Escreve Kant: "Leciona-se sempre a ontologia, a cosmologia, a teologia racional com as provas da existência de Deus, a psicologia racional com as provas da imortalidade da alma, mas não basta que uma disciplina universitária seja matéria de exame para ser levada a sério enquanto ciência" como mostra recentemente a triste experiência do Diamat [materialismo dialético], conforme os depoimentos de professores e estudantes russos na URSS. Mutatis mutandis, o estado da metafísica na Alemanha da segunda metade do século XVIII é um pouco este: tem-se os avalistas da honra da metafísica, Leibniz e Wolf, cujos manuais tiveram importância relevante e bem notada por Kant, mas o prestígio deles resiste mal à ofensiva, à 
polêmica dos newtonianos, notadamente a do mais brilhante polemista entre eles, Leonard Euler. No terreno da ciência positiva, todo mundo pensa que Newton já ganhou. Seus conceitos de movimento, força e inércia são mais operatórios do que as mônadas, essas substâncias metafísicas que Leibniz pretende serem dotadas de percepção. As proposições metafísicas de Leibniz não são falsificáveis e a nova física, escrevem Euler e muitos outros, precisa de outros princípios metafísicos. Visto que não se trata de renegar a metafísica, uma coisa é constatar que a metafísica, até agora, malogrou tornar-se ciência, outra coisa é proclamar o seu óbito. Kant, no seu caderno de notas, que serve muito na elaboração da própria crítica, está utilizando a expressão "crise da metafísica", e mais de uma vez repara com satisfação que essa rainha das ciências se tornou propriedade dos filósofos alemães, do velho pendor germânico pela Gründlichkeit, que resiste às investidas do bom senso comum.

Que Kant tenha sempre guardado na mente a elaboração de uma metafísica entendida como ciência dos primeiros princípios do conhecer humano, que ele tenha assumido o espírito da Gründlichkeit do ilustre Wolf, isso não deve ser esquecido, se se quer medir o exato alcance subversivo da crítica. E a crítica, de uma vez por todas, terá como intuito por fim à crise da metafísica.

Os pródromos da crítica encontram-se na Dissertação de 17r0, primeira amostra de uma ciência propedêutica que deve preceder a metafísica e esclarecer os princípios do entendimento puro. Esclarecer quer dizer mostrar o porquê da abundância de enunciados falsos e confusos dos tratados de metafísica. A razão pura, que é o objeto da metafísica, é o poder de conhecer a priori independentemente da experiência. Kant nunca vai duvidar da existência desse poder. Mas ele chegou relativamente 
cedo a pensar que a metafísica nunca poderia sair do estado humilhante de confusão em que permanecera até então enquanto não fosse regida pelo estoque de recursos da razão pura e não se medisse sua exata competência. A ideia da Dissertação de 1770, onze anos antes da publicação da Crítica, é a seguinte: os metafísicos nunca dissociaram duas fontes totalmente heterogêneas do conhecimento, a sensível e a intelectual. Os extravios da sua pretensa ciência até agora provêm desse desconhecimento, pois nunca reconheceram que esses dois modos de conhecer não têm apenas objetos diferentes, mas as legislações que os regem, as regras do jogo, não são as mesmas nos dois lados, nos dois tipos de conhecimento. Pelo fato de não terem sido atentos a esse ponto, eles decidiram sobre objetos unicamente acessíveis ao intelecto - as substâncias metafísicas de que falava Leibniz, por exemplo - como se na realidade se tratasse de conhecimento. A Dissertação se empenha em pôr fim a essa confusão cometida inconscientemente e assim resguardar, escreve Kant, a metafísica de qualquer traço do sensível. O intuito de Kant em 1770 é evitar esse alastramento do conhecimento sensível à intelecção, e as extrapolações ilegítimas que esta comete. Seria fácil dar exemplos da confusão que produziu erros metafísicos devidos a essa dissociação fundamental. Conclusão da Dissertação: é necessário tomar cuidado para que os princípios do conhecimento sensível não saiam de seus limites próprios para macular os inteligíveis, quer dizer, os objetos acessíveis unicamente ao entendimento. Vou partir da frase que, é claro, não anuncia particularmente a Crítica da razão pura, mas me parece ser um tema que é conservado nessa obra, tema esse que será o desta exposição.

Falar da primeira Crítica em uma hora e meia é expor-se a 
um grande risco. Percorrer um máximo de coisas em um tempo mínimo é arriscar-se a cair num emaranhado de conceitos, o que, invariavelmente, torna a exposição pouco inteligível ou um pouco chata. Escolhi então delimitar este tema da Dissertação: nunca macular os inteligíveis. Meu intuito é mostrar que esse tema desemboca na possibilidade de uma colocação bem mais clara de uma obra destinada a alicerçar de uma vez por todas a filosofia da pretensamente imutável razão pura, de uma tal maneira que, ao fim, veremos aparecer as sombras de Schopenhauer e de Nietzsche. Assim, dividirei esta exposição em quatro partes, assinaladas de forma um tanto escolar. Na primeira parte, eu gostaria de mostrar a mudança do diagnóstico da Dissertação de 1770 até a Crítica de 1781 a respeito do extravio da metafísica até agora - trata-se de duas análises bem diferentes. $\mathrm{Na}$ segunda parte, gostaria de expor melhor essas duas formas de extravio e as duas advertências dirigidas por Kant aos metafísicos. Na terceira parte, gostaria de mostrar a função estratégica do númeno. E, por fim, na conclusão, gostaria de tentar mostrar os pródromos da noção nietzscheana de "interpretação", que me parecem vinculados à manutenção desse primeiro tema que já se encontra na Dissertação de 1770. Tal vai ser o meu caminho.

Estávamos em 1770, vamos pular onze anos, para a Crítica da razão pura, especialmente para o capítulo da "Anfibologia", que é destinado a apurar as contas com Leibniz. Este, como bom metafísico, é acusado de ter cometido uma confusão, um equívoco. Mas o problema é saber se esse equívoco denunciado em 1781 é o mesmo que havia sido denunciado onze anos antes. Essa pergunta pode parecer muito pedante, mas vamos ver que ela é importante para a compreensão do significado exato e até, eu diria, do lugar da Crítica da razão pura. Leibniz desconhecia 
totalmente a heterogeneidade das duas fontes do conhecimento, a sensibilidade e o intelecto, ou melhor, desconheceu, conforme Kant, que há dois modos de ser objeto. Essa dissociação é fundamental. Quem não faz essa dissociação é vítima forçosamente do duplo sentido - daí o título de "Anfibologia" - que pode tomar uma mesma noção, conforme o campo em que ela é encarada: enquanto objeto puro do entendimento ou enquanto objeto da experiência, objeto sensível. Mas Leibniz, e o metafísico em geral, não pensa em estipular o terreno em que ele coloca a sua análise. Tomemos, assim, o exemplo do princípio leibniziano da identidade dos indiscerníveis: duas substâncias individuais não podem ser perfeitamente semelhantes pelo fato de serem duas, quer dizer, elas não podem diferir apenas pelo número. Elas só podem ser ditas legitimamente "duas" se diferem pelo menos por um predicado. Suponhamos, com efeito, duas coisas diferentes, mas completamente semelhantes, de modo que a diferença não estaria apenas nessa dualidade. Essa suposição, diz Leibniz, é contraditória. Dados o conteúdo "a" e o conteúdo "b", desde que "a" é suposto diferente de "b", essa relação, ser diferente de "b", corresponde a um predicado na coisa "a" que não se encontra na coisa "b" (visto que "b" não é diferente de si mesmo). Assim, nós não temos o direito de colocar "a" e "b" como idênticos. Cada vez que há dualidade ou pluralidade, essa dualidade ou pluralidade corresponde a uma diferença na essência das coisas ditas diferentes. Kant não refuta essa tese. Ela, pelo contrário, é inatacável para quem permanece no nível do simples conceito do entendimento, no nível lógico. O que Kant recusa é que se possa aplicar esse princípio a coisas enquanto presentes na intuição sensível, como faz Leibniz ao dizer que nunca há de se encontrar duas folhas de árvore ou dois pingos de água seme- 
lhantes, e ao lançar o desafio às damas de Hannover, para que encontrassem duas folhas iguais no parque do castelo - ao que parece, essas damas nunca voltaram... Não se tem o direito de dar às coisas da intuição sensível determinações que têm validade apenas para as coisas em geral, para as coisas consideradas em si mesmas, quer dizer, abstração feita das condições da intuição sensível. É claro que se poderia falar de coisas no tempo e no espaço como coisas em si mesmas, mas com a condição de estipular a diferença entre elas no discurso filosófico. Pois é no discurso filosófico que as coisas presentes na intuição sensível e as coisas em geral não estão submetidas à mesma legislação, e que as palavras não têm o mesmo significado. Dentro do espaço, o ser de uma coisa ao lado de uma outra coisa - este copo ao lado desta garrafa - é um princípio de diferenciação suficiente, até se as duas coisas forem completamente semelhantes, mas estiverem dentro do espaço. Leibniz porém não pensou a diferença entre coisas no espaço e coisas consideradas apenas conforme o conceito delas. Há dois pontos de vista, dois enfoques diferentes que Leibniz não distinguiu. É preciso ficar atento a essa diferença de enfoques. Quem desconhece essa diferença vai cometer um erro de princípio, responsável pelos extravios da metafísica, mas um erro de princípio - e é isso que me interessa - diferente daquele assinalado por Kant onze anos antes.

Em 1770, Kant falava da transferência sub-reptícia de princípios, cuja validade na realidade era restrita à área do conhecimento sensível, aos objetos do intelecto. Agora, em 1781, trata-se de uma análise muito diferente, trata-se de uma extrapolação, eu diria, na direção inversa. O metafísico está fazendo abstração das condições específicas do conhecimento sensível a tal ponto que os fenômenos de que ele está falando não são mais 
fenômenos, a não ser no nome. É claro que, no espaço, coisas completamente semelhantes podem ser exteriores e serem ditas duas. Leibniz pensa o contrário porque ele se satisfaz com uma fenomenologia, podemos dizer, completamente errada. No entanto, o que me interessa é que da Dissertação para o capítulo III da "Analítica" nós lidamos com dois tipos de erros, responsáveis pelo malogro aterrador da metafísica, bem distintos: o primeiro é devido à influência desapercebida da sensibilidade sobre o modo de pensar; o segundo provém de um total descuido ao que vai caracterizar o conhecimento sensível. Nesse sentido, a análise do erro de princípio cometido pelo metafísico não é mais a mesma. Como entender essa mudança de diagnóstico? Ela só pode ser entendida à luz do conceito mais famoso de Kant, o de idealidade transcendental.

A idealidade transcendental, vou tentar defini-la em poucas palavras, é um conceito que nasce apenas na primeira Crítica e faz com que a análise da sensibilidade não tenha o mesmo alcance e a mesma função que na Dissertação. De 1770 a 1781, a análise da sensibilidade vai sofrer um remanejamento cuja importância é decisiva para o presente ponto, a natureza do extravio do metafísico. Na Crítica da razão pura, Kant caracteriza a sensibilidade, ou melhor, a posse do conhecimento sensível, como o indício do que ele chama de uma receptividade da nossa faculdade de conhecer - e nós veremos que esse possessivo nossa é importante. Esse modo de intuição, escreve ele na "Estética transcendental", é chamado sensível porque ele não é originário, quer dizer, tal que a existência do objeto da intuição seja dada pela intuição, mas depende da existência do objeto e, por conseguinte, só é possível na medida em que a capacidade receptiva do sujeito é afetada pelo objeto. Aprofundando essa diferença 
entre as duas modalidades do conhecer, Kant vai até o ponto de tornar homônimos esses dois tipos de conhecimento: um tipo de conhecimento que deveria ser um conhecimento intelectual, um conhecimento das substâncias metafísicas, por exemplo, que exprime a natureza de seu objeto; e um outro tipo de conhecimento que apenas está dando informação a respeito da recepção de uma mensagem e da incidência que essa mensagem tem sobre a nossa faculdade de conhecer. Essa distinção é fundamental, e ela é o aprofundamento de um tema que já era indicado antes, mas de maneira muito elíptica, na Dissertação de 1770. É a "Estética transcendental" que com uma força impressionante traça esse corte entre um conhecimento que teria acesso ao objeto considerado em si mesmo e o conhecimento que não pode ser determinado a não ser que nós levemos em consideração a natureza do sujeito que conhece. Do segundo modo de conhecimento não se deve esperar qualquer informação sobre o objeto em si mesmo, de modo que o verdadeiro conhecimento não tem o mesmo sentido lá e aqui. A "Estética transcendental" não se cansa de retomar esse ponto: quando se trata do objeto de uma intuição sensível, deve ser ponto pacífico que é impossível dizer algo sobre esse objeto para quem faz abstração da constituição subjetiva de seu conhecimento. Dizer que o espaço e o tempo são as formas da intuição sensível implica em dizer que nós não temos absolutamente o direito de pensá-los a respeito das coisas em geral sem precisar o estatuto delas. Para quem sabe da condição subjetiva, pela qual nós recebemos a intuição externa, a representação do espaço não significa mais nada. Isso é o sentido do famoso idealismo transcendental - a expressão é meio bárbara, eu sei. O significado primordial de idealismo transcendental é este: os objetos da percepção externa (ou da interna) 
não podem por princípio ser determinados como coisas em geral, mas apenas como fenômenos, quer dizer, como coisas enquanto aparecem aos sentidos. Donde já se entende que o idealismo transcendental - mas isso Kant não conseguiu evitar, esse contrassenso, apesar de suas próprias advertências - não tem nada a ver com uma doutrina do conhecimento que põe em dúvida ou vai desvalorizando a existência de um objeto percebido. É algo totalmente diferente o que exprime o idealismo transcendental - é uma opção ontológica: os objetos que estão aparecendo no espaço e no tempo não devem ser estudados, tratados e considerados como coisas que poderiam ser dadas previamente à representação humana e que poderiam ser considerados independentemente da representação humana. Esses aparecimentos - se aceitarmos traduzir assim Erscheinungen - não são de forma alguma aparências ou fantasmas. Ao contrário, eles têm consistência. Mas o filósofo quer simplesmente frisar, ao declarar a fenomenalidade deles, que são coisas no espaço e no tempo, e que filosoficamente essas coisas devem sempre se relacionar com a idealidade transcendental. Isso quer dizer que o espaço não é nada para quem aceitaria considerá-lo como podendo fundamentar qualquer tipo de coisa no espaço por referência à nossa sensibilidade.

Conforme as páginas da "Estética transcendental" que comentamos atrás, pode-se dizer que a filosofia Crítica não é de forma alguma a constatação de qualquer maldição que proíba as pessoas de conhecerem as coisas em si, que estariam disfarçadas, por assim dizer, atrás de uma cortina, e que estaríamos encerrados - coitados de nós - em uma ciência dos fenômenos. Essa representação da chamada finitude, essa representação demasiadamente acanhada da ciência, é um ponto que me parece capital. 
Kant está se apoiando em uma análise completamente inédita da sensibilidade, apenas esboçada em 1770, e está apresentando o conhecimento sensível como sendo absolutamente exclusivo do modo de representação que diria respeito aos inteligibilia, quer dizer, aos objetos do metafísico. Basta pensar nas mônadas de Leibniz. Desde logo, o erro maior de uma metafísica como a de Leibniz é ter ignorado essa especificidade do conhecimento sensível, e essa pretensão falsifica por princípio qualquer discurso relativo ao sensível. É preciso devolver todo o peso à crítica formulada contra Leibniz, que foi levado a um ponto de vista absolutamente falso, e que, com isso, elaborou uma fenomenologia falsa - e eu estou apenas expondo a análise de Kant, não quero ser responsável por qualquer desprezo para com Leibniz.

Assim, a "Estética transcendental", pelo trabalho que ela opera sobre a noção de sensibilidade, permite entender melhor por que a crítica à metafísica parece ter sofrido um deslocamento desde a Dissertação de 1770. Em que consiste esse deslocamento? Vamos começar pela ideia da Crítica. O metafísico na Dissertação é acusado de transferir aos fenômenos, quer dizer, aos objetos que só têm consistência enquanto temas do conhecimento sensível, propriedades que convém apenas aos objetos considerados em si mesmos. Essa transferência é possibilitada pela falta de dissociação dos dois domínios. A "Estética" tem essa dissociação, e é por isso que Kant é tão atento ao esquema fenômeno/coisa em si, aos dois enfoques. Um exemplo: como a palavra metafísica "substância" poderia ter um mesmo significado enquanto objeto da intuição sensível, o fenômeno, ou enquanto um em si? Como uma substância dentro do mundo sensível, se é que é possível falar de substância? Mas então não se entende o que significa dizer que essa substância é simples, quer dizer, abso- 
lutamente, radicalmente composta. Sendo sensível, dentro do espaço, ela só pode ser divisível, visto que a divisibilidade no espaço não conhece limites. Quer dizer, nós temos um bom exemplo de uma homonímia total entre a substância no sentido de um fenômeno e a substância no sentido de ser inteligível. Mas é a dissociação dessas duas regiões, desses dois enfoques fenômeno e coisa em si -, himmelweit verschiedene, diferentes in totum, que permite a dissociação dos dois significados da palavra metafísica como "substância" e permite evitar sistematicamente o amálgama cometido pelos metafísicos. Tal é, parece-me, a razão da mudança de diagnóstico a respeito do erro fundamental e do erro de princípio da metafísica.

Entre 1770 e 1781 nós vamos encontrar, na obra de Kant, duas formas de denúncia da metafísica, ou melhor, de análise do extravio cometido pelo metafísico. Se nós voltarmos agora ao meu ponto de partida, encontraremos a recomendação essencial que em 1770 era dirigida aos metafísicos - todo o método metafísico, que diz respeito ao sensível e aos inteligíveis, reduz-se essencialmente a este preceito: tomar grande cuidado com os princípios próprios do conhecimento sensível para que não saiam de seus limites próprios e maculem os inteligíveis. Conforme essas linhas, o perigo que aguarda o metafísico é bem diferente da armadilha em que Kant põe Leibniz, conforme as análises da Crítica da razão pura. Na Dissertação, o metafísico tem uma confiança irrefletida em princípios que, na realidade, estão validados no campo do conhecimento sensível. E, assim, as proposições que afirma sobre o inteligível, sobre a substância, correm o risco de ser falsificadas. Na Crítica da razão pura, trata-se de algo completamente diferente: o metafísico está ignorando totalmente a especificidade do sensível e está impondo ao sensível (é só pen- 
sar no princípio dos indiscerníveis) uma legislação que não é a dele. Ele está traindo o sensível.

Mas não são apenas duas etapas da crítica da metafísica. Acontece que esses dois temas, e é este o ponto que me interessa, permanecem juntos, e, às vezes, merecem ser distinguidos dentro da obra crítica. Não tenho tempo de analisar, mas seria fácil ver, notadamente no capítulo III da "Analítica transcendental", que Kant tem de impor dois temas diferentes que o leitor deve guardar na mente conjuntamente: em primeiro lugar, a idealidade transcendental, que é a única teoria que permite fundamentar o caráter apodítico da matemática e da físico-matemática; em segundo lugar, não deve esquecer que essa vantagem da idealidade transcendental é vinculada com a radicalidade da tomada de posição ontológica de Kant, não deve esquecer que a idealidade primordialmente faz com que eu só possa falar da natureza do objeto na medida em que o objeto está relacionado unicamente com as representações que eu tenho dele. Assim, existem duas precisões que nós temos de enunciar taxativamente quando falamos de coisas justapostas no espaço: essas coisas são consideradas em relação com a intuição sensível e, segundo Kant, dizem respeito ao nosso modo humano de intuição. Essas duas indicações não são superficiais. Se não se guardar essas duas indicações, poder-se-ia professar a filosofia crítica, mas seria dogmatizar insidiosamente a filosofia de Kant. Com isso, omitiríamos forçosamente este fato: que a filosofia crítica está se apresentando em permanência e explicitamente como um exame da condição subjetiva do conhecimento, ou ainda, da experiência do nosso conhecimento empírico em geral. É preciso prestar atenção à força desses possessivos: não experiência em geral, mas a nossa experiência; não intuição em 
geral, mas o nosso modo de intuição; não entendimento em geral, mas a nossa forma discursiva de entendimento. Quem vai atenuando, por pouco que seja, a força distintiva desses possessivos - nosso, nosso -, chega forçosamente a atribuir de maneira indevida, a qualquer ser que conhece, a restrição incluída nesses possessivos. A gente se encontra na situação analisada e denunciada no escrito de 1770.

Kant, também na Crítica da razão pura, volta ao tema da sub-repção da Dissertação. Há um texto famoso, no fim dos Prolegômenos, quando ele está distinguindo dois esquemas sofísticos igualmente ruinosos para a filosofia, tendo em conta a análise prévia da objetividade. Há duas formas de extravio: a primeira é aquela clássica do metafísico que acredita poder sem nenhuma dúvida enunciar juízos sintéticos teológicos e cosmológicos a priori, fora dos limites da experiência possível. Esse é o mais conhecido erro metafísico assinalado por Kant. Mas esse texto dos Prolegômenos fala de uma outra forma de extravio, bem distinta do erro metafísico: a que consiste em levar ao absoluto as condições restritivas próprias à noção lógica do conhecer. No importante parágrafo 57 dos Prolegômenos haveria um absurdo ainda maior, o de pretender que a nossa experiência é o único modo de conhecimento possível. Nós estamos assim precavidos de duas formas de pretensão e ignorância. A primeira consiste em não se perguntar o que a condição dos fenômenos do conhecer nos autoriza a admitir enquanto objeto - essa é a mais clássica e mais famosa. A segunda consiste em fazer abstração da situação, que é a nossa, enquanto seres que conhecem, e assim considerar a faculdade de conhecer humana como sendo o padrão da faculdade de conhecer em geral. Ao primeiro pendor, a crítica opõe a famosa injunção de se evi- 
tar os juízos transcendentes da razão pura que ultrapassam a área da possibilidade da experiência. Em contrapartida, para se combater o segundo pendor, Kant acrescenta, como ele diz nos Prolegômenos, "a ordem apenas em aparência oposta" (das dem Anschein nach streitende Gebot), a ordem em conflito com o primeiro pendor, conforme ela aparece, a ordem de ir até os conceitos que se encontram fora do campo do uso empírico para mostrar melhor que o seu uso é apenas empírico, reservado a uma espécie de animal racional entre outros possíveis. Entre essas duas injunções, evitar o juízo atrevido do metafísico e evitar confundir o nosso modo de conhecer com o padrão de qualquer tipo de conhecimento, o conflito é só aparente, temos de sustentar de uma vez que nada pode ter valor de objeto para nós que ultrapasse a possibilidade da experiência. E é importante dizer que não se trata da experiência, mas da possibilidade da experiência. Sem essa precisão não haveria diferença essencial entre Kant e Hume. Esse é o primeiro ponto. Em segundo lugar, essa proibição, essa impossibilidade de emitir proposições fora do campo da experiência não é proferida no absoluto, ela só vale para nós. Em suma, nós temos que manter juntos esses dois temas, que não são conflitantes, mas que podem ser facilmente dissociados, resguardando-nos de recair na reflexão que possibilitou o discurso metafísico bem como naquela que cai no positivismo e no cientificismo, e devemos recusar, para tanto, a ideia de uma coisa que deve ser pensada não como objeto dos sentidos, mas como uma coisa em si, unicamente para o entendimento puro. Nós não temos o direito de excluir isso como sendo absurdo. Esse conceito operatório, encarregado de lembrar-nos, nós que estamos lendo a Crítica da razão pura e escrevendo sobre ela, muito mais que a nossa finitude, a nossa 
situação geográfica dentro do mundo dos seres vivos. Esse conceito operatório, um dos mais fascinantes da Crítica, é chamado de númeno.

$\mathrm{Na}$ terceira parte dessa minha exposição, eu gostaria não de apresentar essa noção tão difícil em Kant, mas de mostrar em que medida ele está reatando, no coração da Crítica, com o espírito que estava guiando os textos da Dissertação de 17r70. Um dos melhores comentários sobre a noção de númeno foi feito antes da Crítica da razão pura: o númeno é o incompreensível, e, como incompreensível, não deixa de ser o número infinito, o espaço infinito igual ao finito. Sim, é Pascal que comentou por antecipação: "É inacreditável que Deus se una conosco. Essa consideração só é retirada da nossa baixa condição, mas é um sentimento muito sincero". E mais à frente: "é preciso reconhecer que a nossa situação com efeito é tão baixa que nós somos incapazes de saber se a misericórdia divina não poderia afinal nos tornar capazes de conhecer em uma certa medida. Eu gostaria de saber da onde esse animal se dá o direito de medir a misericórdia de Deus e impor os limites que a sua fantasia nos sugere". Isso é realmente a estratégia enunciada e efetivada pela noção de númeno na Crítica. Não se trata de designar qualquer objeto misterioso e inacessível. A palavra designa apenas algo não sensível, conceito muito radical do que não pode ser absolutamente contido em uma intuição sensível, até de uma maneira mínima. Ora, nós não estamos em condição de dizer o que poderia ser um tal conteúdo extrassensível. Kant leva o rigorismo até recusar tomar em conta a distinção tradicional entre mundo dos sentidos (Sinnnenwelt) e mundo do entendimento (Verstandenwelt). Seria dizer demais. Por que chamar de mundo o conjunto dos seres extrassensíveis? Vamos mais 
adiante nessa direção. Não se pode afirmar a existência desse mundo, não se pode afirmar a existência de coisas não sensíveis. Para poder afirmar essa existência nós teríamos que ter a certeza de que eles são acessíveis a uma outra intuição, diferente da sensível. E nós não podemos admitir a existência dessa outra intuição. De certo, para nós, a intuição sensível é a única possível. E essa restrição basta para que o conceito de númeno não seja algo contraditório. Todavia, nós não podemos demonstrar também que uma outra espécie de intuição seja possível, de modo que nós somos (cito Kant) "completamente incapazes de apanhar a possibilidade de tais objetos e, a fortiori, de afirmar a existência deles". Kant entende assim por númeno um conceito unicamente problemático. E o que quer dizer problemático? Uma representação de uma coisa, da qual não se pode dizer nem que é possível, nem que é impossível. Porque nós não conhecemos outro modo de intuição que não seja a nossa intuição sensível e nem outro modo de entendimento que não seja o nosso, de categorias. Nenhum desses dois modos de conhecer é apropriado a um objeto extrassensível. É preciso lembrar que a palavra noumenon designa em grego o tema do conhecimento pelo nous inteligível. Aqui, a palavra será interpretada - não sei se se diz isso em português - a contremploi. No cinema e no teatro, uma atriz distinta no papel de uma mulher da zona é utilizada a contremploi. A palavra númeno é utilizada aqui $a$ contremploi. Ela não é utilizada para sugerir o conceito de um objeto inteligível. Até se vocês acrescentassem que esse objeto é inacessível a nossa mente, devido a nossa finitude, já seria um contrassenso, porque seria subentender que esse objeto, que se encontra oculto, seria suscetível de alargar, de estender o nosso conhecimento de como ele é. E Kant faz múltiplas advertências 
contra essa tentação de dar a uma coisa de pensamento ( $G e$ dankending) um estatuto de objeto, de ultra-objeto. Eu posso até conceber um ser absolutamente simples, o elemento último que não comporte mais elementos, como a mônada de Leibniz, o átomo metafísico, mas isso não me dá, de forma alguma, o direito de afirmar que há um mundo suprassensível efetivamente composto de mônadas, que, por assim dizer, duplicaria o mundo dos corpos. Isso realmente seria forjar um mundo encantado - e "mundo encantado" parece uma brincadeira positivista. Isso não quer dizer que não tenho o direito de pensar os inteligíveis como objetos. Mas tenho também de negar a possibilidade de coisas que ultrapassam totalmente a estrutura da nossa faculdade de conhecer. É isso que o númeno está encarregado de lembrar.

Neste ponto, tenho vontade de fazer uma pergunta trivial: de que adianta conservar uma rubrica encarregada de demarcar o lugar problemático de um não-objeto? Tentarei responder a esta pergunta, se a noção de númeno é imprescindível. Na medida em que ela designa (cito Kant) "uma coisa que deve ser pensada não como objeto dos sentidos, mas como coisa em si, quer dizer, unicamente por um entendimento puro, e simplesmente por essa razão". A pergunta pode ser retomada, porque é indispensável fazer essa estipulação. Para entendermos isso, retomemos o exemplo do ser absolutamente simples, da mônada. Quando estou convencido de que esse ser jamais pode ter o valor de um objeto de conhecimento, no sentido tradicional, estou tentado a afirmar a impossibilidade absoluta dessa noção e debochar desses seres metafísicos. Por certo essa noção de mônada não é contraditória, visto que não está excluído que ela dê sentido a um outro modo de conhecimento completamente diferente. Mas, para Kant, a não-contradição não autoriza afirmar a possibili- 
dade de uma coisa - essa tese agressivamente anti-leibniziana é sustentada por Kant desde muito tempo e retomada com força no "Exame crítico dos conceitos modais dos postulados do conhecimento empírico". Nunca se pode afirmar a possibilidade de algo unicamente pelo exame dos puros conceitos. Por exemplo: que haja uma faculdade particular da nossa mente para intuir o futuro, para ver o futuro, como Cassandra, a profetisa. É uma possibilidade que não é contraditória, certamente, mas a experiência faz com que ela tenha de ser rejeitada. Mesmo a possibilidade das coisas fundada em conceitos a priori, como, por exemplo, as grandezas contínuas e as grandezas em geral, só pode ser afirmada com referência às condições da determinação dos objetos na experiência. Desde logo, por que não incluir a noção de puro inteligível nessa rubrica das possibilidades inconsistentes? Essa pergunta tem de ser posta com muita força, visto que parece haver uma tensão com a doutrina kantiana das modalidades. E aqui passamos a um outro tipo de discurso por isso me demorei nessa noção tão difícil de númeno. Uma possibilidade inconsistente (como a da pretensa faculdade de predizer o futuro) que tem de ser rechaçada é, segundo Kant, uma ligação arbitrária de pensamentos que, embora não contendo contradição alguma, não pode pretender a uma realidade objetiva e nem, por conseguinte, a possibilidade de um objeto como deve ser pensado aqui. É certamente o caso do númeno. O númeno é, por definição, o conceito vazio, no que diz respeito à objetividade. Então por que conservar o númeno como conceito operatório fundamental? A única resposta me parece ser essa: para tomar um recuo a respeito da única fonte - e eu vou forjar aqui um barbarismo - da "objetalidade", da forma de ser objeto. Objetividade que faz sentido para nós. Que essa atitude seja 
útil, pelo menos metodologicamente, o texto do parágrafo 57 dos Prolegômenos traz um exemplo disso. Quando Kant opõe às proposições metafísicas que o metafísico não se cansa de asseverar e também essa outra forma mais insidiosa de orgulho não metafísico, que consiste em julgar como sendo quimérica qualquer noção metafísica desprovida de realidade objetiva, é Hume quem está sendo visado. E é a noção de númeno que está encarregada de fazer obstáculo a esse segundo pendor, a essa segunda propensão. Por isso é preciso conservar essa noção, à primeira vista esdrúxula, de não-objeto de uma intuição sensível. Noção metodologicamente indispensável, simplesmente pelo fato de que ela designa, assim como a noção de simples absoluto da mônada, algo enquanto deve ser distinguido dos objetos dos sentidos, que são todos compostos e apresentados como composições. Esse lugar reservado a um tipo de objetos problemáticos - e tão problemáticos que devem ser chamados apenas de não-objetos da intuição sensível - pertence à vocação limitadora da crítica da razão por si mesma. Em suma, Kant nos informa que há certas coisas de que se pode falar: o ser simples, o ser necessário que contém todas as possibilidades, etc. Não por acaso, são sempre conceitos leibnizianos. Mas eles não podem ser considerados como objetos dos sentidos, objetos da percepção, objetos físicos. E é necessário lembrar, de modo suplementar, que nós falamos de objetos relativamente à nossa estrutura de conhecimento. O papel do conceito, ou melhor, do "transconceito" de númeno é marcar o lugar de um não-objeto, como não sendo absolutamente nada, e com isso combatemos os efeitos do que Kant chama de presunção da sensibilidade, ou melhor, de "presunção do conhecimento sensível", o fato de debochar sistematicamente de qualquer proposição metafísica. Com 
isso, estou terminando a terceira parte da minha exposição.

O intuito de Kant em 1770 era preservar o inteligível das usurpações do conhecimento sensível. Esse risco desaparece desde que o inteligível não pertence mais, na Crítica da razão pura, ao campo dos objetos do conhecimento. Mas o mesmo tipo de perigo volta novamente de forma mais insidiosa quando o entendimento desconhece que a validade de suas operações é estrita e delimitada ao campo da experiência possível e, esquecido dessa limitação, decide a respeito dos inteligíveis como se a sua existência, o seu estatuto, pertencesse à jurisdição do entendimento. É por isso que, para nos resguardarmos dessa pretensão, dessa hybris do entendimento, temos que conservar a noção de númeno, temos que combater essa Anmassungen. E não se trata mais da pretensão do metafísico de provar a existência da alma, mas a pretensão do físico que (eu cito) "considera a nossa experiência como sendo o único modo de conhecimento possível e, por conseguinte, a nossa intuição do espaço como sendo a única possível". Esse saber peca, em suma, pelo antropocentrismo. A noção de númeno é encarregada de combater a tentação de antropocentrismo, esse saber não está atento ao fato de que ele é próprio ao homem, e nem está atento ao fato de que esse modo de conhecer é estritamente específico para abalar o imperialismo espontâneo do saber hipostasiado dos físicos. É preciso lembrar permanentemente que a nossa ciência foi construída por uma espécie determinada de seres razoáveis entre muitas outras espécies possíveis, e cujo aparelho de conhecimento poderia ser constituído de uma outra maneira.

Chego à minha conclusão. Não se deve esquecer que Nietzsche, jovem filólogo, ficou entusiasmado com a filosofia de Kant via Schopenhauer e quis redigir uma tese de filosofia, mas não 
teve sorte; o departamento de filosofia de Leipzig não gostou da ideia, e com isso nós fomos privados de um trabalho cujo tema era o juízo biológico do fim da Crítica do juízo de Kant. Quer dizer, ver lá, via Schoppenhauer, a raiz da noção nietzscheana de Deutung, de interpretação, não me parece uma coisa gratuita. Esse tema, de uma modéstia que ultrapassa o sentido corriqueiro da palavra modéstia, nunca foi tão bem trabalhado por Kant quanto no fim da Crítica do Juízo, notadamente nos vertiginosos parágrafos 75 a 78, quando o autor precisa o estatuto do conhecimento do ser vivo. Ele acaba de reconhecer que o ser orgânico possui certos traços específicos, como a faculdade de duplicação, de reprodução, etc., que, observa Kant, o destacam dos outros objetos de conhecimento. De modo que, acatando essa especificidade, não posso conhecê-lo no mesmo registro, como se fosse um ser inorgânico. Desde que eu fique atento a essa originalidade do ser vivo, só poderei me referir a ele ou julgá-lo como se ele tivesse sido organizado por um produtor inteligente. Essa leitura espontaneamente finalista é incontornável, como representante de uma outra maneira de formação, a economia tão complexa do ser vivo. Poderia ser ela, salvo engano, simples efeito de um acaso? Nós temos que recorrer a esse subterfúgio (porque não passa de um subterfúgio). Nós temos que dar a esse como se toda a sua força, visto que essa forma de causalidade representa muito mais do que jamais poderíamos saber, até seria absurdo de considerá-la como sendo o equivalente de um princípio científico. Nada justifica a utilização desse conceito, de uma causalidade técnica (a respeito do ser vivo), a não ser a impossibilidade em que estamos de relegá-lo ao plano da contingência absoluta. Mas então, em que medida essa máxima teleológica-finalista, desprovida de qualquer valor teórico, é di- 
ferente de uma ficção que a nossa mente tem de forjar? Kant sabe muito bem que é assim, mas seria muito difícil mostrar como ele consegue, no fim da Crítica do Juízo, evitar essa equivalência da máxima teleológica com uma ficção. Nesse sentido, eu quero apenas tematizar um único ponto. Seria um erro, diz Kant, pensar que em si, no absoluto, não pode haver compreensão dos seres orgânicos a partir das forças mecânicas que agem na natureza. Somos nós que, devido a nossa estrutura de conhecimento, somos incapazes dessa proeza. Mas por que fazer da nossa faculdade o padrão de qualquer conhecimento? Quer dizer, nós não temos o direito de ser antimaterialistas. Pode ser que, no absoluto - e basta ver o parágrafo 75 da terceira Crítica - haja um outro entendimento, capaz de encontrar a articulação entre o inorgânico e o ser organizado. Nós não temos o direito de afirmar a tese da produção dos corpos organizados por meio do jogo das forças mecânicas, mas nada também permite rechaçar essa tese. Como diz Kant no parágrafo 75, seria uma pretensão desmedida julgar assim. Mesmo que fosse possível penetrar no coração da natureza, nunca se encontraria a própria formação dos seres vivos e nunca se poderia derivá-la do simples mecanismo, der Wohlwollen wider wissende. Onde nós poderíamos saber disso? Exatamente por isso citei Pascal, "je voudrais bien savoir d'où ils savent cela". Nessas páginas bastante surpreendentes da Crítica do Juízo, o intuito de Kant é, antes de mais nada, negar ao entendimento, de maneira total, o direito de emitir sentença de impossibilidade no absoluto - como se ele fosse capaz de tanto, como se o que é impensável para ele devesse ser declarado absurdo e incompreensível "tout ce qui est incompréhensible ne laisse pas d'être". Se se descarta toda a possibilidade de uma formação inteiramente mecânica 
do ser organizado, é porque se pensa que há em si incompatibilidade entre os modos de produção orgânico e inorgânico. Isso redunda em colocar que qualquer ser que pensa e conhece deve relacionar ao fato orgânico a causalidade intencional de um autor da natureza, e que, no absoluto, o ser vivo não pode ser conhecido a não ser pelo esquema teleológico, pelo esquema finalista. Mas poderia haver um outro entendimento, funcionando de maneira completamente diferente do nosso. Nos parágrafos 76 e 77 da terceira Crítica há uma metafísica com toque de fiç̧ão, Kant mostra como poderia funcionar esse entendimento. $\mathrm{E}$, para esse entendimento, não haveria necessidade de recorrer à finalidade, à produção de um autor inteligente. Em suma, poderiam haver gênios, como gostava de dizer Leibniz, para os quais a conciliação da inteligibilidade mecânica com o orgânico não poria sombra de dificuldade. É indispensável, conforme diz Kant, ter sempre em mente esse ideal típico do outro entendimento (usemos a palavra weberiana Artifex), mais elevado que o entendimento humano, para lembrarmos permanentemente que não é qualquer ser que conhece que, para pensar em um ser vivo, precisa se valer de uma analogia técnica com a cláusula do como se. Acontece que nós somos obrigados a conceber o ser vivo dessa maneira, mas essa concepção não é típica daquele que deveria formar todos os seres razoáveis possíveis. Isso é posto unicamente pela disposição própria das nossas faculdades de conhecer. Com isso, gostaria de falar um pouco dos parágrafos 76 e 77, que estão entre as coisas mais prodigiosas que Kant escreveu: a descrição desse outro entendimento que pensaria o ser vivo completamente sem a finalidade. O parágrafo 76 realmente merece ser sempre lido e relido, pois parece questionar afinal de contas até o próprio lugar da filosofia kantiana. 
Bom, eu perguntava o que vale a ideia de uma conjunção do mecânico com o orgânico. A investigação de Kant nos parágrafos 76 e 77 leva-nos a essa conclusão: que um conceito como esse não deve ser rechaçado no absoluto, mas deve permanecer problemático. Entretanto, assim como o númeno, deve ser sempre levado em consideração precisamente para nos preservar da tentação de considerar depressa demais como sendo impensáveis no absoluto soluções que estão simplesmente fora do alcance do entendimento humano em virtude da sua conformação. Então, se formos conferir novamente os textos de 1770, que eu citei desde o começo, podemos constatar que Kant, vinte anos depois, na Crítica do Juízo, de 1790, determina mais uma vez a mesma forma de inconsciência e irreflexão que ele apontara em certos metafísicos que, pelo fato de terem delimitado as condições do conhecimento humano sensível, afirmam no absoluto proposições (como a de que não pode haver infinito atual), que não valem em realidade a não ser com relação ao exercício desse modo de conhecimento. Por exemplo: é impossível que algo seja e não seja ao mesmo tempo, quer dizer, isso é contraditório. É uma conclusão leviana, no sentido de que o entendimento só capta a impossibilidade quando consegue elaborar a enunciação simultânea dos opostos a respeito do mesmo sujeito e objeto. Há nisso uma contradição. Por conseguinte, quando essa condição não se apresenta (Dissertação, parágrafo 28), nenhum juízo sobre a impossibilidade pode ser emitido pelo entendimento humano. Mas deduzir que isso não é permitido a qualquer entendimento, e deduzir que tudo o que não envolve contradição é possível, seria concluir apressada e levianamente. Levianamente, porque não se suspeita que a validade desse enunciado poderia restringir-se ao campo do conhecimento sensível que é, pelo menos para nós 
todos, a condição sine qua non de qualquer conhecimento de objetos para nós homens, pela disposição idiossincrática das nossas faculdades de conhecer. O perigo portanto permanece. E Kant fica atento a isso em toda a sua obra: que o filósofo possa desconhecer que, em última instância, a estrutura do conhecimento é um factum característico da condição própria à nossa espécie. E que a nossa faculdade de conhecer ao encontrar um objeto como o corpo organizado tem de se valer do esquema da produção intencional, devido à disposição humana do conhecer. Se for assim, como poderíamos ter a certeza de que qualquer outra espécie de seres racionais encontram-se forçosamente na mesma situação? E, entretanto, é essa certeza implícita que permitiu à físico-teologia afirmar dogmaticamente, não por meio da cláusula como se, um Deus artista, autor de uma providência, etc. A filosofia crítica leva-nos a uma modéstia muito, muito maior, leva-nos a reconhecer que um outro aparelho de conhecimento poderia muito bem pensar a unidade própria do ser vivo, do ser orgânico, sem forjar o esquema da causalidade final. Seria um absurdo se, e apenas se, os seres materiais fossem coisas em si. Então, por certo seria inconcebível que no absoluto o entendimento fosse incapaz de conhecer a organização própria de um ser vivo segundo a causalidade mecânica sem recorrer ao menos à ideia da causalidade técnica. Como está escrito no parágrafo 77 da Crítica do Juízo, como é pelo menos possível considerar o mundo material como simples fenômeno, não se pode excluir a ideia de uma articulação dos dois modos de causalidade, embora sendo completamente inacessível ao nosso entendimento. Esse tema, que surge em flashes entre 1770 e 1790, é muito distinto do tema da revolução copernicana. Será que se deve, a respeito dela, como fazem alguns comentadores, falar em um 
aprofundamento da finitude? Confesso que não gosto dessa palavra finitude aplicada a Kant, porque ela me parece abstrata demais, finitude pode cobrir mecanismos bem diferentes. Para esse tema, que tentei evocar, preferiria falar de um desenraizamento maximal do antropocentrismo. Não tenho certeza que a palavra finitude seja apropriada para dar conta da revolução de pensamento que vai aqui se esboçando. Pelo menos por uma razão: a palavra finitude é dificilmente separável da ideia de uma limitação do poder de conhecer próprio da criatura enquanto criatura. Por certo que a Crítica da razão pura, no espírito de seu autor, teria sido impossível sem a convicção tão importante da limitação da nossa razão. Todavia, o leitor que ficasse atento somente a essa ideia poderia conceber a filosofia de Kant como sendo o prolongamento ou o acabamento das filosofias que Foucault chamava de "finitudes negativas", características, conforme ele, do pensamento representativo da idade clássica. Ora, Kant vai muito mais adiante dessa "finitude limitativa" - definida pela limitação, pela carência do ser criado comparado com o criador. Ele vai até mesmo sugerir que nós não passamos de uma espécie que não tem o direito de medir o conhecer em geral pelo standard das próprias performances cognitivas. Nossa capacidade de conhecer, que se nutre de duas fontes - razão e intuição sensível -, não é um padrão de qualquer forma de conhecimento, e a análise do juízo sobre os seres orgânicos, dos seres vivos, é a prova de que ela obriga essa faculdade de conhecer própria a criar, pela necessidade de nossas representações, ficções ou interpretações que seriam bastante irrisórias de propor como sendo o modelo de um saber em geral de qualquer ser que conhece.

Uma dúvida então acaba surgindo: seríamos assim constituídos para que nossa representação possa ser sinônimo de falsifi- 
cação - para dar conta, por exemplo, da especificidade de uma região da natureza como o ser vivo? Um texto muito belo de Kant, o parágrafo 72 da Crítica do juízo, sugere essa tese: se os homens se deixam conhecer pela físico-teologia é porque a concordância contingente dos seres orgânicos com os nossos conceitos de arte e de técnica (vou citar em alemão) "fälschiche für eine besondere Art der Naturerzeugung ausgedeutet werde". Ausgedeutet! Trata-se, talvez, de uma das primeiras ocorrências da Deutung, da interpretação, no sentido nietzscheano. A concordância contingente dos seres orgânicos com o nosso conceito de técnica é falsamente interpretado como um modo particular de produção natural. Mas o texto não formula exatamente a posição de Kant. A neutralidade crítica não lhe permite é claro confundir a máxima teleológica com o princípio ontológico, teológico, mas não lhe permite também determinar uma leitura falsificadora da realidade pelo fato de ele se utilizar da analogia técnica. É Schopenhauer que, no suplemento do Mundo como vontade, seguindo de muito perto a Crítica do Juízo, vai afirmar o caráter falsificador da representação da finalidade: quando o intelecto admira a finalidade orgânica da natureza, ele só admira na realidade a sua própria obra. E, assim sendo, ele retoma a mentira da velha físico-teologia. Essa mentira é a seguinte: a finalidade orgânica seria incompreensível se o mundo, antes de existir, não tivesse sido a representação de um intelecto supremo que depois o produziu tecnicamente. E Schopenhauer acrescenta (ele gosta dessa fórmula), "eu afirmo, pelo contrário, no sentido de Kant: se o mundo deve ser representação, ele tem de se manifestar como tendo uma finalidade. E isso ocorre dentro do nosso intelecto. O absurdo é, por ignorância desse mecanismo, projetar a produção técnica lá, no mundo". É claro 
que tal é a leitura de um dissidente da Crítica do Juízo. Mas é uma leitura que não é absurda. Deslocando algumas peças, é possível chegar à interpretação de Schopenhauer.

Mas com Schopenhauer nós não estamos mais no terreno da filosofia da razão pura, que quer fazer a síntese da razão pura, que quer apresentar o quadro exaustivo dela. Com Schopenhauer tudo mudou, ele virou a mesa: é o mundo que se representa a si mesmo mediante o sistema nervoso chamado superior de uma das espécies de seres vivos que ele produziu. Assim sendo, é muito pouco verossímil que essa representação, essa filtragem operada pelas necessidades de nossa sobrevivência, chegue a desvendar algo da realidade - por ser pouco verossímil, para falar agora de maneira nietzscheana, que Apolo esteja em condição de dizer a verdade a Dionísio.

Que esse pensamento radicalmente ateu e naturalista seja formado na esteira de uma filosofia destinada a garantir para sempre os direitos da razão pura, é também uma demonstração clara do surpreendente gênio de Kant. Esse era o tema que eu queria apresentar.

\section{Apêndice}

LEBRUn EXPÕE SUBSOlO DA FILOSOFIA DE KAnT Marcelo Rezende (Folha de São Paulo, Caderno Ilustrada, 9/11/1995)

Quais os limites da razão? E de que forma são estabelecidos e articulados no pensamento do filósofo alemão Immanuel Kant? Durante quase duas horas, o professor francês Gérard Lebrun tentou responder essas questões, na noite de anteontem, na palestra "O Subsolo da Crítica". O auditório, com capacidade para 
84 pessoas, estava lotado. Sua exposição é parte do ciclo de palestras A Crise da Razão, organizado pela Funarte. O professor Lebrun, que durante seis anos lecionou na Universidade de São Paulo - entre 1960 e 1966 -, é um dos maiores historiadores da filosofia. Atualmente lecionando em Aix-en-Provence, na França, Lebrun é autor de Kant e o Fim da Metafísica e O Avesso da Dialética, entre outras obras, que serviram como livros de formação para uma geração de filósofos. Enquanto esperava para dar início à palestra, Lebrun disse à Folha que preferia se manter em silêncio sobre o suicídio do também filósofo Gilles Deleuze, ocorrido em Paris no último sábado. "O Caso Deleuze" era um dos temas frequentes na platéia que aguardava sua entrada: "Eu não gostaria de falar nada. Ainda mais sobre uma situação tão triste. E acho que Deleuze não apreciaria pronunciamentos". Mas, ainda que involuntária, sua palestra se ligou, ao menos no tema, a um dos trabalhos clássicos de Deleuze: Para ler Kant. Lebrun iniciou, às 19h41, uma introdução sobre os conceitos da Crítica da Razão Pura de Kant. Falou sobre de que forma este trabalho, que estabelece a impossibilidade da metafísica como ciência, tem raízes em um trabalho anterior: a Dissertação de 1770. Segundo Lebrun, a "Dissertação" mostra que Kant ainda acreditava em um conhecimento metafísico, um saber especulativo sobre temas como Deus e a alma, que será mais tarde rompido. Mas, que nunca deixaria de percorrer a obra do filósofo, se estabelecendo o que Lebrun chama de "uma crítica subterrânea". Lebrun prosseguiu mostrando que, ao contrário do que afirmam alguns comentadores, os limites impostos pelo filósofo à razão (demonstrando o que é possível conhecer) cumprem a tarefa de arrancar o homem de seu antropocentrismo. Sua exposição terminou às $21 \mathrm{~h} 26$, quando foi permitido ao público fazer 
perguntas. Como não houve qualquer manifestação, o professor Gérard Lebrun pediu licença a todos para contar algo que, segundo ele, tinha pouco a ver com Kant. Lebrun falou sobre sua volta ao antigo prédio da rua Maria Antonia: "Gostaria de falar sobre a minha experiência de hoje a tarde, minha caminhada do largo do Arouche até a Maria Antonia. Algo que não fiz por razões sentimentais, mas que me emocionou muito. Voltar ao lugar onde lecionei há quase 30 anos, onde o presidente da república passou sua tese... voltar foi emocionante". 